\title{
NAUJAGIMIŲ SKAUSMO VALDYMAS: SLAUGOS SPECIALISTŲ ŽINIOS IR VEIKLA
}

\author{
Silva Kostyliovienè $\dot{1}^{1,2}$, Alina Vaškelytė ${ }^{1,3}$, Dovilè Grinkevičiūtè ${ }^{2,4}$, \\ Gretẻ Seniūnaité丶 ${ }^{\mathbf{1}}$, Rasa Vainutytè ${ }^{\mathbf{1}}$ \\ ${ }^{1}$ Kauno kolegijos Medicinos fakulteto Slaugos katedra, \\ ${ }^{2}$ Lietuvos sveikatos mokslu universiteto ligonine Kauno klinikos, Vaiku intensyviosios terapijos \\ skyrius, ${ }^{3}$ Lietuvos sveikatos moksly universiteto Slaugos fakulteto Slaugos ir rüpybos katedra, \\ ${ }^{4}$ Lietuvos sveikatos mokslu universiteto Medicinos fakulteto Vaiku ligu klinika
}

Raktažodžiai: naujagimiai, skausmo vertinimas ir malšinimas, slaugos specialistų žinios ir veikla.

\section{Santrauka}

Naujagimiai, kuriems reikalingas gydymas, intensyvi priežiūra ir slauga ligoninëje, patiria vidutiniškai nuo 7,5 iki 17,3 skausmingų procedūrų per dieną [4]. Dažniausios yra dūris ị kulną paimti kapiliarinio kraujo ėminį, sekreto išsiurbimas iš kvẻpavimo takų ir venos punkcija. Tyrimais ịrodyta, kad nemalšinamas skausmas daro poveikị vaiko raidai. Sveikatos priežiūros specialistams gali būti ypač sunku ịvertinti neišnešioto, sunkiai sergančio ar turinčio neurologinị pažeidimą naujagimio skausmą. Skausmo vertinimui rekomenduojama naudoti skausmo vertinimo skales. Naujagimių skausmą rekomenduojama mažinti pakopomis, taikant tinkamas aplinkos, nefarmakologines ir farmakologines skausmo malšinimo priemones.

Tyrimo tikslas - išanalizuoti slaugos specialistų naujagimių skausmo valdymo žinias ir veiklą, atsižvelgiant ị išsimokslinimą ir darbo patirtį.

Tyrimas vyko nuo 2019 metų lapkričio 4 d. iki gruodžio15 d. X miesto ligoninèse ir gimdymo namuose, slaugos specialistų anoniminès anketinès apklausos metodu. Buvo išdalinta 120 klausimynų, grịžo tinkami analizei 70. Atsako dažnis $-58,33$ procento.

Tyrimo rezultatai atskleidè, kad didžioji dalis slaugos specialistų, turinčių aukštaji universitetinị ir aukštajj neuniversitetinị išsimokslinimą bei mažesnę darbo patirtị, lyginant su turinčiais aukštesniji išsimokslinimą bei didesnę darbo patirtị, žinojo apie skausmo žalą naujagimiams, skausmo vertinimo ypatumus, naudojant PIPP skalę, nerekomenduojamus medikamentus naujagimių skausmo malšinimui. Tyrimo dalyviai nurodè, kad klinikinèje praktikoje naujagimių skausmo vertinimui dažniau naudojo PIPP skalę, taikè nemedikamentinius skausmo malšinimo metodus, vietinị nuskausminimą EMLA kremu, naudojo acetaminofeną (paracetamolį).

\section{Ivadas}

Skausmas nuo seno buvo ir yra didelè sveikatos priežiūros problema. Visais laikais buvo ieškoma būdų, kaip skausmą vertinti ir malšinti. Prancūzų filosofas Renee Descartes $1664 \mathrm{~m}$. pirmasis pavaizdavo skausmo kelią ir suteikè pagrindą vadinamajai specifiškumo teorijai [1]. Tarptautinè skausmo tyrimų asociacija (IASP) $2020 \mathrm{~m}$. liepos mènesị pateikè atnaujintą skausmo apibrěžti: ,,skausmas - tai nemaloni jutiminè ir emociné patirtis, susijusi ar panaši i faktini ar galimą audinių pažeidimą [2].

Skausmas - viena dažniausių slaugos problemų, su kuriomis susiduria slaugytojai klinikineje praktikoje. Naujagimiams, ypač neišnešiotiems, dažnai atliekamos skausmingos procedūros, kai jie gydomi ir slaugomi naujagimių intensyviosios terapijos ar naujagimių ligų skyriuose. Naujagimiai, kuriems reikalingas gydymas, intensyvi priežiūra ir slauga ligoninejje, per pirmąsias 14 nuo gimimo ar patekimo ị stacionarą dienų, patiria nuo 832 iki 42413 invazinių procedūrų, vidutiniškai nuo 7,5 iki 17,3 skausmingų procedūrų per dieną [4]. Dažniausios yra dūris ị kulną paimti kapiliarinio kraujo èmini, sekreto išsiurbimas iš kvėpavimo takų ir venos punkcija bei kateterizacija [4]. Siekiant išvengti naujagimiui žalingo skausmo poveikio, būtina skausmą vertinti ir malšinti. Tyrimų rezultatai rodo, kad ne visada atliekamas naujagimių skausmo vertinimas $[5,6]$. Tyrimo, vykdyto 18 Europos šalių 243 naujagimių intensyviosios terapijos skyriuose (NITS), išvadose pasakyta, kad ilgai trunkantis skausmas buvo įvertintas mažiau nei trečdaliui NITS gydytų pacientų ir kasdien įvertinamas 10 procentų naujagimių [5]. 
Naujagimių skausmo valdymas yra sudètingas procesas, nes jie negali patys pasakyti apie skausmą, todèl ypač sunku įvertinti neišnešiotų, sunkiai sergančių ar turinčių neurologinių pažeidimų naujagimių skausmą. Svarbu, kad visi sveikatos priežiūros specialistai, dalyvaujantys šių naujagimių ir kūdikių priežiūros procese, gebètų ìvertinti bei tinkamai valdyti jų skausmą [7-9]. Siekiant tiksliau ir objektyviau įvertinti naujagimių skausmą, būtina naudoti skausmo vertinimo priemones - skales [8]. Atlikto tyrimo rezultatai parodè, kad ne visada naujagimio skausmo vertinimui taikomos skausmo vertinimo skalès [10]. Naudojant skales, skausmas vertinamas stebint naujagimio elgesio požymius (veido išraišką, rankų ir kūno judesius, verksmo dažnị ir pobūdị, raumenų tonusą, miego sutrikimus, nusiraminimą) ir fiziologinius skausmo rodiklių pokyčius (ŠSD, KD, AKS, $\mathrm{SPO}_{2}$, odos spalvą, vyzdžio dydį, delnų prakaitavimą, hormonų - kortizolio, katecholaminų koncentraciją kraujyje) [12].

Lietuvoje teisès aktai nurodo, kad slaugytojas turi išmanyti skausmo valdymo principus, gebeti nustatyti skausmo intensyvumą naudodamas skausmo skalę bei pagal gydytojo paskyrimą ir paciento poreikị naudoti skausmo valdymo vaistiniais ir ne vaistiniais preparatais priemones, teikti būtinają medicinos pagalbą [13]. Naujagimio skausmo malšinimo metodikoje, kuriai pritarè ir Lietuvos Neonatologijos asociacija, pateikiamos detalios naujagimio skausmo vertinimo ir malšinimo rekomendacijos, o skausmo vertinimui rekomenduojama naudoti PIPP skausmo vertinimo skalę [14].

Ivertinus naujagimio skausmo intensyvumą, rekomenduojama taikyti pakopinius skausmo malšinimo būdus, naudojant nefarmakologinius ir farmakologinius metodus $[8,9,12,14]$. Esant silpnam skausmui, rekomenduojami nefarmakologiniai skausmo malšinimo metodai, tokie kaip oda prie odos kontaktas, žindymas ar motinos pienas (MP), sensorinis stimuliavimas (lietimas: glostymas ar masažavimas; skonio: gliukozė ar MP; klausos: niūniavimas ar kalbinimas; regos: žiūrèjimas ị naujagimị) [12].

Kai naujagimiui duriama ị kulną paimti kraujo èminị, punktuojama periferinè vena ar arterija, atliekamos injekcijos ị raumenis ar paodị, kartu su nefarmakologiniais skausmo malšinimo metodais galima taikyti vietinị nuskausminimą, pvz., EMLA (2,5 proc. lidokaino $+2,5$ proc. prilokaino) $[12,14]$. Esant stipresniam dūrio i pirštą, kulną ar žaizdos perrišimo skausmui, rekomenduojama naudoti acetaminofeną. Kai numatomos labai skausmingos procedūros, tokios kaip žaizdų tvarkymas, pleuros drenažas, intubacija, skausmo malšinimui rekomenduojama naudoti opiatus $[12,14]$.

Tyrimo tikslas - išanalizuoti slaugos specialistų naujagimių skausmo valdymo žinias ir veiklą.

Tyrimo medžiaga ir metodai
Tyrimas vyko nuo 2019 metu lapkričio 4 iki gruodžio 15 dienos $\mathrm{X}$ miesto ligoninėse ir gimdymo namuose. Tyrimo metodas - anoniminè anketinè apklausa. Tyrimo dalyviai slaugos specialistai, slaugantieji naujagimius.

Klausimyną sudare 21 klausimas, susijęs su skausmo vertinimu, nemedikamentiniais ir medikamentiniais skausmo malšinimo metodais, medikamentų dozuotėmis, skausmo vertinimo skalemis, skausmo balais, skausmo neigiamu poveikiu naujagimiui, jo elgesio pokyčiais.

Tyrimui vykdyti gautas tiriamujų įstaigų vadovų ir LSMU bioetikos centro pritarimas.

Tyrime dalyvauti buvo pakviesti visų tiriamujų ịstaigu stacionarų slaugos specialistai $(\mathrm{n}=120)$, kurie slaugo naujagimius. Buvo išdalinta 120 klausimynų, grižo tinkami analizei 70. Atsako dažnis - 58,33 procento.

Pagal išsimokslinimą, kiek mažiau nei pusè (44,3 proc., $\mathrm{n}=31$ ) tyrime dalyvavusių slaugos specialistų turèjo aukštesnij̣ išsimokslinimą, igytą medicinos mokykloje; mažiau nei trečdalis $(31,4$ proc., $n=22)$ - aukštaji universitetinį ir kiek daugiau nei penktadalis (24,3 proc., $\mathrm{n}=17$ ) aukštajị neuniversitetinị išsimokslinimą. Daugiau nei pusė $(57,1$ proc., $n=40)$ respondentų nurodè turintys didesnę nei 10 metų darbo patirti, kiek daugiau nei penktadalis $(22,9$ proc., $n=16)$ nuo 5 iki 10 metų ir penktadalis $(20,0$ proc., $n=14)$ - mažesnę nei 5 metų darbo patirti.

Statistinei tyrimo duomenu analizei naudota SPSS 24.0 (angl. Statistical Package for the Social Sciences) programa. Analizuojant tyrimo duomenis, nagrinejjamų požymių pasiskirstymas imtyje buvo aprašomas procentiniu dažniu (proc.) ir skaitine charakteristika (n). Požymių skirtumas tarp tiriamųjų grupių laikytas statistiškai reikšmingu, kai reikšmingumo lygmuo $\mathrm{p}<0,05$.

\section{Tyrimo rezultatai}

Tyrimo metu siekta sužinoti respondentų nuomonę apie žalingą patiriamo skausmo poveikị naujagimio sveikatai. Analizuojant rezultatus buvo nustatyta, kad atsižvelgiant i respondentų darbo patirtí, didžiosios dalies $(93,8$ proc., $\mathrm{n}=15$ ) slaugos specialistų, turinčių 5-10 metų darbo patirtį, nuomone, neivertintas ir negydomas skausmas gali sutrikdyti naujagimio psichomotorinę raidą; taip pat manè statistiškai reikšmingai mažesnè dalis slaugos specialistų, turinčių mažesnę nei 5 metų $(71,4$ proc., $\mathrm{n}=10)$ ir didesnę nei 10 metų $(47,5$ proc., $n=19)$ darbo patirti $(\mathrm{p}=0,004)$. Pusès $(50,0$ proc., $\mathrm{n}=20$ ) respondentų, turinčių daugiau nei 10 metų ir kiek daugiau nei pusès $(64,4$ proc., $n=9)$, turinčiu mažesnę nei 5 metų darbo patirti, nuomone, neicvertintas ir negydomas skausmas gali paveikti naujagimio pažintinę, motorinę, jutiminę, somatosensorines ir centrines funkcijas. Taip manè ir statistiškai reikšmingai didesnè dalis (87,5 proc., $\mathrm{n}=14)$ tyrimo dalyvių, 
turinčių 5-10 metų darbo patirti $(\mathrm{p}=0,033)$. Apie penktadalis $(20,0$ proc., $n=8)$ slaugos specialistų, turinčių didesnę nei 10 metu darbo patirti, atsakè, kad nevertinamas ir nemalšinamas skausmas nedaro žalos naujagimio sveikatai, tačiau taip nemanė nè vienas slaugos specialistas, turintis mažesnę nei 5 ar 5-10 metų darbo patirti $(\mathrm{p}=0,033)$ (1 lentelè).

Analizuojant tyrimo rezultatus atsižvelgiant ị respondentų išsimokslinimą, nustatyta, kad didžiosios dalies slaugos specialistų, turinčių aukštajj neuniversitetini $(82,4$ proc., $n=1)$ ir aukštaji universitetini ( 72,7 proc., $n=16)$ išsimokslinimą, nuomone, neivvertintas ir negydomas skausmas gali sutrikdyti psichomotorinę raidą, tačiau taip manè statistiškai reikšmingai mažesnè dalis (45,2 proc., $\mathrm{n}=14)$ aukštesnijị išsimokslinimą turinčių slaugos specialistų $(\mathrm{p}=0,02)$. Apie pusè $(45,4$ proc., $\mathrm{n}=14$ ) tyrimo dalyvių, aukštesniji išsimokslinimą igiję medicinos mokykloje, manè, kad neịvertintas ir negydomas skausmas gali paveikti pažintinę, motorinę, jutiminę, somatosensorines ir centrines funkcijas. Taip mane statistiškai reikšmingai didesnè dalis tyrime dalyvusių slaugos specialistų, turinčiu aukštaji neuniversitetinị $(76,5$ proc., $n=13)$ ir aukštaji universitetini $(72,7$ proc., $\mathrm{n}=16)$ išsimokslinimą $(\mathrm{p}=0,043)(1$ lentelè).

Atlikus slaugos specialistų nuomonès analizę, ar sunku atlikti skausmo vertinimą dèl riboto bendravimo, susijusio su amžiumi, reikšmingų skirtumų tarp darbo patirties grupių nenustatyta. Didžioji dalis tiriamujuc $(93,8$ proc., $n=15)$, turinčių 5-10 metų darbo patirtí, bei daugiau nei pusè, turinčių mažesnę nei 5 metų $(71,4$ proc., $\mathrm{n}=10)$ ir didesnę nei 10 metų $(62,5$ proc., $n=25)$ patirti, pritare, kad pediatrijoje sunku atlikti skausmo vertinimą dèl riboto bendravimo, susijusio su amžiumi. Panašūs rezultatai gauti ir atsižvelgiant ị respondentų išsimokslinimą. Didesnès dalies respondentų, turinčių aukštajị neuniversitetinị ( 82,6 proc., $n=14)$, aukštesniji (71,0 proc., $n=14)$ ir aukštaji universitetini $(63,6$ proc., $n=14)$ išsilavinimą, nuomone, pediatrijoje sunku atlikti skausmo vertinimą dèl riboto bendravimo, susijusio su amžiumi.

Kad naujagimių skausmo vertinimui reikia naudoti skausmo vertinimo skales, teigè didesnè dalis slaugos specialistų, turinčių daugiau nei 10 metų $(77,5$ proc., $n=31)$, mažiau nei 5 metų ( 85,7 proc., $n=12)$ ir 5-10 metų $(87,5$ proc., $n=14$ ) darbo patirtį. Didesnè dalis respondentų, turinčių aukštaji universitetini ( 90,9 proc., $n=20$ ), aukštajį neuniversitetini ( 88,2 proc., $n=15)$ ir aukštesniji $(71,0$ proc., $n=22)$ išsimokslinimą sutiko, kad dirbant su naujagimiais, skausmo vertinimui reikia naudoti skausmo vertinimo skales.

Siekta nustatyti, kokias skausmo vertinimo skales klinikinejje praktikoje naujagimių skausmui vertinti naudoja respondentai. Tyrimo rezultatai parodè, kad atsižvelgiant ị išsimokslinimą, didesne dalis tiriamujų nurodè, kad dažniausiai naudoja PIPP, FLACC ir N-PASS skausmo vertinimo skales: respondentai, turintys aukštesniji išsimokslinimą (atitinkamai 80,6 proc., $\mathrm{n}=25 ; 58,1$ proc., $\mathrm{n}=18 ; 12,9$ proc., $\mathrm{n}=4$ ), aukštaji neuniversitetini (atitinkamai 82,4 proc., $\mathrm{n}=14$; 52,9 proc., $n=9 ; 23,5$ proc., $n=10$ ), aukštaji universitetini (atitinkamai 77,3 proc., $\mathrm{n}=17$; 45,5 proc., $\mathrm{n}=10$ ir 45,5 proc., $\mathrm{n}=10$ ). Panašūs rezultatai nustatyti, atsižvelgiant ị darbo patirtị. Didesnè dalis respondentų nurodè, kad naujagimių skausmo vertinimui dažniausiai naudoja PIPP, FLACC ir

1 lentelè. Neįvertinto ir nenumalšinto skausmo žala naujagimiams

\begin{tabular}{|c|c|c|c|c|c|c|}
\hline \multicolumn{3}{|c|}{ Darbo patirtis, metais } & \multirow{3}{*}{$\begin{array}{c}\text { Galimo neicvertinto ir } \\
\text { nenumalšinto skausmo žala }\end{array}$} & \multicolumn{3}{|c|}{ Išsimokslinimas } \\
\hline$<5$ & $5-10$ & $>10$ & & $\begin{array}{l}\text { aukštes- } \\
\text { nysis }\end{array}$ & $\begin{array}{l}\text { aukštasis } \\
\text { neuniversi- } \\
\text { tetinis }\end{array}$ & $\begin{array}{l}\text { aukštasis } \\
\text { universite- } \\
\text { tinis }\end{array}$ \\
\hline \multicolumn{3}{|c|}{ proc. (n) } & & \multicolumn{3}{|c|}{ proc. (n) } \\
\hline $71,4(10)$ & $93,8(15)$ & $47,5(19)^{*}$ & $\begin{array}{l}\text { Gali sutrikti } \\
\text { psichomotorinè raida }\end{array}$ & $\begin{array}{r}45,2 \\
(14)^{*}\end{array}$ & $82,4(14)$ & $72.7(16)$ \\
\hline $71,4(10)$ & $93.8(15)$ & $65,0(26)$ & $\begin{array}{l}\text { Gali sukelti emocinius, elgesio bei } \\
\text { pažinimo funkcijos sutrikimus }\end{array}$ & $\begin{array}{r}54,7 \\
(17)^{*} \\
\end{array}$ & $82,4(14)$ & $90,9(20)$ \\
\hline 0 & 0 & $20,0(8)^{*}$ & $\begin{array}{l}\text { Skausmas jokios žalos } \\
\text { nedaro }\end{array}$ & $19,4(6)$ & $5,9(1)$ & $5,9(1)$ \\
\hline $64,3(9)$ & $87,5(14)$ & $\begin{array}{l}50,0 \\
(20)^{*}\end{array}$ & $\begin{array}{l}\text { Gali paveikti pažintinę, motorinę, } \\
\text { jutiminę, somatosensorines ir cen- } \\
\text { trines funkcijas }\end{array}$ & $45,4(14)^{*}$ & $76,5(13)$ & $72,7(16)$ \\
\hline $64,3(9)$ & $75,0(12)$ & $62,5(25)$ & Gali sukelti ilgalaikę baimę & $51,6(16)$ & $76,5(13)$ & $77,3(17)$ \\
\hline $78,6(11)$ & $62,5(10)$ & $75,0(30)$ & Galimi valgymo sutrikimai & $71,022)$ & $76,5(13)$ & $72,7(16)$ \\
\hline $78,6(11)$ & $93,8(15)$ & $85,0(34)$ & Galimi miego sutrikimai & $80,6(25)$ & $82,4(14)$ & $95,5(21)$ \\
\hline \multicolumn{4}{|c|}{$* \mathrm{p}<0,05$, lyginant $\mathrm{su}<5 \mathrm{~m}$. ir 5-10 m. } & ukštuoju & universiteti & ir universi- \\
\hline
\end{tabular}


N-PASS skausmo vertinimo skales: turintys mažiau nei 5 metu patirti (atitinkamai 71,4 proc., $n=10 ; 50,0$ proc., $n=7$ ir 42,9 proc., $n=6$ ), 5-10 metų patirti (atitinkamai 75,0 proc., $\mathrm{n}=12 ; 62,5$ proc., $\mathrm{n}=10$ ir 12,5 proc., $\mathrm{n}=2$ ), daugiau nei 10 metu patirti (atitinkamai 85,0 proc., $n=34 ; 50,0$ proc., $\mathrm{n}=20$ ir 25,0 proc., $\mathrm{n}=10)$. Daugiau nei dešimtadalis $(12,5$ proc., $\mathrm{n}=2$ ) slaugos specialistų, turinčių 5-10 metų darbo patirti, nurodè, kad klinikinèje praktikoje naujagimių skausmui vertinti naudoja COMFORT skausmo vertinimo skalę. Šios skalès nenaudojo nè vienas slaugos specialistas, turintis mažiau nei 5 , ar daugiau nei 10 metų darbo patirti $(\mathrm{p}=0,031)$.

Tyrimo metu siekta sužinoti, kokius požymius vertina slaugos specialistai, kai naujagimio skausmo vertinimui naudoja PIPP skausmo vertinimo skalę. Analizuojant duomenis, atsižvelgiant į respondentų išsimokslinimą, buvo nustatyti statistiškai reikšmingi skirtumai tarp grupių. Statistiškai reikšmingai mažesnè dalis $(58,1$ proc., $\mathrm{n}=18)$ slaugos specialistų, turinčių aukštesnijji išsimokslinimą, lyginant su slaugos specialistais, kurių išsimokslinimas yra aukštasis neuniversitetinis $(88,2$ proc., $\mathrm{n}=15)$ ir aukštasis universitetinis $(90,9$ proc., $\mathrm{n}=20$ ), nurode, kad naujagimio skausmo vertinimui naudodami PIPP skalę, vertina nosies lūpų raukšlès gilumą $(\mathrm{p}=0,009)$. Reikšmingai didesnè dalis slaugos specialistų, turinčių aukštajį universitetini $(95,5$ proc., $n=21)$ ir aukštaji neuniversitetini ( 82,2 proc., $\mathrm{n}=14$ ) išsimokslinimą, lyginant su aukštesniji $(67,7$ proc., $n=21)$ išsimokslinimą turinčiais slaugos specialistais, vertindami naujagimio skausmą PIPP skale, vertino ŠSD pokyčius ( $\mathrm{p}=0,044)$. Reikšmingai didesné dalis tiriamųjų, turinčių aukštaji neuniversitetinị $(88,2$ proc., $\mathrm{n}=15)$ ir aukštaji universitetinị $(86,4$ proc., $\mathrm{n}=18)$ išsimokslinimą, lyginant su aukštesniji (51,6 proc., $\mathrm{n}=16)$ išsimokslinimą turinčiais slaugos specialistais, vertino $\mathrm{SpO}_{2}$ pokyčius, kai naujagimio skausmo vertinimui naudojo PIPP skausmo vertinimo skalę $(p=0,005)$. Statistiškai reikšmingai mažesnè dalis (38,7 proc., $n=12)$ respondentų, turinčių aukštesnijj išsimokslinimą, lyginant su respondentais, kurių išsimokslinimas yra aukštasis neuniversitetinis $(82,4$ proc., $n=14)$ ir aukštasis universitetinis ( 81,8 proc., $n=18)$, nurodé, kad vertinant naujagimio skausmą PIPP skale, vertina ir naujagimio gestacini amžių $(p=0,001)$ ( 2 lentelè). Atsižvelgiant i respondentų darbo patirtị, statistiškai reikšmingai mažiau respondentų, turinčių daugiau nei 10 metų darbo patirtị $(47,5$ proc., $\mathrm{n}=19)$, lyginant su turinčiais mažiau nei 5 metų $(78,6$ proc., $n=11)$ ir 5-10 metų ( 87,5 proc., $n=14)$ darbo patirti, nurode, kad vertinant naujagimių skausmą PIPP skale, vertina ir naujagimio gestacini amžių $(p=0,008)$ ( 2 lentelè). Apie pusè tyrimo dalyvių teigè vertinantys AKS pokyčius, o maža dalis - vyzdžių išsiplètimą, traukulius, kurie nèra vertinami, naudojant PIPP skausmo vertinimo skalę (2 lentelè).

Analizuojant, kokius nefarmakologinius skausmo malšinimo metodus slaugos specialistai naudojo naujagimių skausmui malšinti klinikinèje praktikoje, atsižvelgiant ị išsimokslinimą, buvo nustatyta, kad dažniau naudoja 12-24 proc. gliukozès tirpalą (aukštesnysis $-93,5$ proc., $n=29$; aukštasis neuniversitetinis $-94,1$ proc., $n=16$; aukštasis universitetinis $-81,8$ proc., $n=18$ ), oda prie odos kontaktą (aukštesnysis - 74,2 proc., $\mathrm{n}=23$; aukštasis neuniversitetinis $-88,8$ proc., $n=15$; aukštasis universitetinis $-68,2$ proc., $n=15$ ), žindymą

2 lentelė. Naujagimio skausmo vertinimas, naudojant PIPP skalę

\begin{tabular}{|c|c|c|c|c|c|c|c|}
\hline \multicolumn{3}{|c|}{ Darbo patirtis, metais } & \multirow{4}{*}{\multicolumn{2}{|c|}{$\begin{array}{l}\text { PIPP skalèje vertinami } \\
\text { požymiai }\end{array}$}} & \multicolumn{3}{|c|}{ Išsimokslinimas } \\
\hline \multirow[t]{2}{*}{$<5$} & $5-10$ & \multirow[t]{3}{*}{$>10$} & & & \multirow{2}{*}{$\begin{array}{l}\text { aukštes- } \\
\text { nysis }\end{array}$} & \multirow{2}{*}{$\begin{array}{c}\text { aukštasis } \\
\text { neuniversi- } \\
\text { tetinis }\end{array}$} & \multirow{2}{*}{$\begin{array}{c}\text { aukštasis } \\
\text { universite- } \\
\text { tinis }\end{array}$} \\
\hline & & & & & & & \\
\hline \multicolumn{2}{|r|}{ proc. (n) } & & & & & proc. (n) & \\
\hline $92,9(13)$ & $75,0(12)$ & $75,0(28)$ & \multicolumn{2}{|c|}{ Nosies ir lūpų raukšlès gilumas } & $58,1(18)^{*}$ & $88,2(15)$ & $90,9(20)$ \\
\hline $92,9(13)$ & $81,3(13)$ & $80,0(32)$ & \multicolumn{2}{|c|}{ Akių užmerkimas } & $74,2(23)$ & $88,2(15)$ & $90,9(20)$ \\
\hline $92,9(13)$ & $81,3(13)$ & $90,0(36)$ & \multicolumn{2}{|c|}{ Antakių suraukimo stiprumas } & $87,1(27)$ & $88,2(15)$ & $90,9(20)$ \\
\hline 0 & $6,3(1)$ & $12.5(5)$ & \multicolumn{2}{|c|}{ Vyzdžių išsiplėtimas } & $12,9(4)$ & $5,9(1)$ & $4,5(1)$ \\
\hline $85,7(12)$ & $87,5(14)$ & $87,5(30)$ & \multicolumn{2}{|c|}{ ŠSD pokyčiai } & $67,7(21)^{*}$ & $82,4(14)$ & $95,5(21)$ \\
\hline $92,9(13)$ & $75,0(12)$ & $62,5(25)$ & \multicolumn{2}{|l|}{$\mathrm{SpO}_{2}$ pokyčiai } & $51,6(16)^{*}$ & $88,2(15)$ & $86,4(18)$ \\
\hline $35,7(5)$ & $68,8(11)$ & $50,0(20)$ & \multicolumn{2}{|l|}{ AKS pokyčiai } & $45,2(14)$ & $52,9(9)$ & $59,1(13)$ \\
\hline 0 & 0 & $5(2)$ & \multicolumn{2}{|l|}{ Traukuliai } & $3,2(1)$ & $5,9(1)$ & 0 \\
\hline $78,6(11)$ & $87,5(14)$ & $47,5(19)^{*}$ & \multicolumn{2}{|c|}{$\begin{array}{l}\text { Nėštumo trukmė (gestacinis } \\
\text { amžius) }\end{array}$} & $38,7(12)^{*}$ & $88,2(14)$ & $81,8(18)$ \\
\hline 0 & 0 & $1,4(1)$ & Temperatūra & & 0 & $5,9(1)$ & 0 \\
\hline \multicolumn{4}{|c|}{$* \mathrm{p}<005$, lyginant $\mathrm{su}<5 \mathrm{~m}$. ir $5-10 \mathrm{~m}}$. & \multicolumn{4}{|c|}{$\begin{array}{l}* p<0,05 \text {, lyginant su aukštuoju (neuniversitetiniu ir uni- } \\
\text { versitetiniu) }\end{array}$} \\
\hline
\end{tabular}


(aukštesnesnysis $-87,1$ proc., $\mathrm{n}=27$; aukštasis neuniversitetinis $-88,2$ proc., $\mathrm{n}=15$; aukštasis universitetinis $-72,7$ proc., $\mathrm{n}=16$ ), naujagimio suvystymą (aukštesnysis $-71,0$ proc., $\mathrm{n}=22$; aukštasis neuniversitetinis $-82,4$ proc., $\mathrm{n}=14$; aukštasis universitetinis - 77,3 proc., $\mathrm{n}=17$ ). Atsižvelgiant $\mathfrak{i}$ išsimokslinimą, nustatytas statistiškai reikšmingas skirtumas tarp grupių, taikant naujagimio skausmo malšinimui ramią aplinką. Didesnė dalis respondentų, turinčių aukštajj neuniversitetini $(94,1$ proc., $n=16)$ ir aukštaji universitetini (72,7 proc., $\mathrm{n}=16)$ išsimokslinimą, lyginant su aukštesniji $(51,6$ proc., $n=16)$ išsimokslinimą turinčiais tyrimo dalyviais, naujagimių skausmo malšinimui sudare ramią aplinką $(\mathrm{p}=0,009)(3$ lentelè).

Atsižvelgiant ị tyrimo dalyvių darbo patirtị buvo nustatyta, kad naujagimių skausmo mašinimui slaugos specialistai dažniausiai naudoja 12-24 proc. gliukozès tirpalą ( $<5$ m. patirtis $-92,9$ proc., $n=13 ; 5-10$ m. patirtis $-75,0$ proc., $\mathrm{n}=12$; $>10$ m. patirtis $-95,0$ proc., $\mathrm{n}=38$ ), oda prie odos kontaktą ( $<5 \mathrm{~m}$. patirtis $-71,4$ proc., $\mathrm{n}=10 ; 5-10 \mathrm{~m}$. patirtis $-87,5$ proc., $\mathrm{n}=14 ;>10 \mathrm{~m}$. patirtis $-72,5$ proc., $\mathrm{n}=29)$, žindymą $(<5 \mathrm{~m}$. patirtis $-85,7$ proc., $\mathrm{n}=12 ; 5-10$ m. patirtis $-68,8$ proc., $\mathrm{n}=11$; $>10 \mathrm{~m}$. patirtis $-87,5$ proc., $\mathrm{n}=35)$, suvystymą, glostymą $(<5 \mathrm{~m}$. patirtis $-92,9$ proc., $\mathrm{n}=13 ; 5-10 \mathrm{~m}$. patirtis $-75,0$ proc., $\mathrm{n}=12 ;>10 \mathrm{~m}$. patirtis $-70,0$ proc., $\mathrm{n}=28$ ). Statistiškai reikšmingai didesnè dalis $(92,9$ proc., $\mathrm{n}=13)$ slaugos specialistų, kurių darbo patirtis mažesnè nei 5 metai, lyginant su slaugos specialistais, kurių darbo patirtis $5-10$ metu $(68,8$ proc., $\mathrm{n}=11)$ ir daugiau nei 10 metų ( 60,0 proc., $n=16)$, naujagimio skausmo malšinimui sudare ramią aplinką $(\mathrm{p}=0,045)$ (3 lentelè).

Klinikinejje praktikoje didesnè dalis slaugos specialistų, atsižvelgiant ị išsimokslinimą, naujagimio skausmo malši- nimui naudojo acetaminofeną (paracetamoli) (aukštesnysis $-74,2$ proc., $\mathrm{n}=23$; aukštasis neuniversitetinis $-58,8$ proc., $\mathrm{n}=15$; aukštasis universitetinis $-68,2$ proc., $\mathrm{n}=17$ ); morfiną (aukštesnysis - 48,4 proc., $\mathrm{n}=15$; aukštasis neuniversitetinis $-88,8$ proc., $\mathrm{n}=10$; aukštasis universitetinis $-68,2$ proc., $\mathrm{n}=15$ ); midozolamą (aukštesnysis $-38,7$ proc., $\mathrm{n}=12$; aukštasis neuniversitetinis $-52,9$ proc., $n=12$; aukštasis universitetinis $-54,5$ proc.).

Buvo nustatyta, kad didesnè dalis slaugos specialistų, turinčių aukštajį universitetinį išsimokslinimą ( 81,8 proc., $\mathrm{n}=18$ ), lyginant su slaugos specialistais, turinčiais aukštesniji $(51,6$ proc., $n=12)$ ir aukštaji neuniversitetini $(52,9$ proc., $\mathrm{n}=9)$ išsimokslinimą, skausmo malšinimui naudojo vietini anestetiką EMLA kremą $(\mathrm{p}=0,049)$. Labai maža dalis $(3,2$ proc., $n=1$ ) respondentų, turinčių aukštesniji išsimokslinimą, nurodè, kad naujagimio skausmo malšinimui naudojo metamizolo natrio druską (analginą). Šio medikamento nenaudojo nei vienas slaugytojas, turintis aukštajị neuniversitetinị ir aukštajj universitetinị išsimokslinimą (4 lentelè).

Analizuojant tyrimo rezultatus, atsižvelgiant ị respondentų darbo patirtị, respondentai teigè, kad naujagimių skausmo mašinimui klinikinejje praktikoje naudojo acetaminofeną (paracetamoli) $(<5 \mathrm{~m}$. patirtis $-92,9$ proc., $n=13$; 5-10 m. patirtis $-81,1$ proc., $\mathrm{n}=13$; $>10 \mathrm{~m}$. patirtis $-72,5$ proc., $n=29)$, morfiną $(<5 \mathrm{~m}$. patirtis $-42,9$ proc., $n=6 ; 5-10$ m. patirtis $-75,0$ proc., $n=12 ;>10 \mathrm{~m}$. patirtis $-55,0$ proc., $n=22)$, midozolamą $(<5 \mathrm{~m}$. patirtis $-50,0$ proc., $n=7 ; 5-10$ m. patirtis $-43,8$ proc., $n=7 ;>10 \mathrm{~m}$. patirtis $-47,5$ proc., $\mathrm{n}=19)$, EMLA kremą $(<5 \mathrm{~m}$. patirtis $-50,0$ proc., $\mathrm{n}=7 ; 5-10$ m. patirtis $-87,5$ proc., $n=12 ;>10 \mathrm{~m}$. patirtis $-60,0$ proc., $\mathrm{n}=24)$ (4 lentelè).

Analizuojant slaugos specialistų žinias apie medikamen-

3 lentelè. Slaugos specialistų taikomi nefarmakologiniai skausmo malšinimo metodai

\begin{tabular}{|c|c|c|c|c|c|c|}
\hline \multicolumn{3}{|c|}{ Darbo patirtis, metais } & \multirow{4}{*}{$\begin{array}{c}\text { Nefarmakologiniai } \\
\text { skausmo malšinimo } \\
\text { metodai }\end{array}$} & \multicolumn{3}{|c|}{ Išsimokslinimas } \\
\hline \multirow[t]{2}{*}{$<5$} & $5-10$ & \multirow[t]{3}{*}{$>10$} & & \multirow[t]{2}{*}{ aukštesnysis } & \multirow{2}{*}{$\begin{array}{c}\text { aukštasis } \\
\text { neuniversite- } \\
\text { tinis }\end{array}$} & \multirow{2}{*}{$\begin{array}{c}\text { aukštasis } \\
\text { universite- } \\
\text { tinis }\end{array}$} \\
\hline & & & & & & \\
\hline \multicolumn{2}{|r|}{ proc. (n) } & & & & proc. (n) & \\
\hline $71,4(10)$ & $87,7(14)$ & $72,5(29)$ & Oda prie odos kontaktas & $73,2(23)$ & $88,2(15)$ & $68,2(15)$ \\
\hline $14,3(2)$ & $12,5(2)$ & $7,5(3)$ & Muzika & $6,5(2)$ & $5,9(1)$ & $18,2(4)$ \\
\hline $92,9(13)$ & $75,0(12)$ & $95,0(38)$ & 12-24 proc. gliukozès tirpalas & $93,5(29)$ & $94,1(16)$ & $81,8(16)$ \\
\hline $85,7(12)$ & $68,8(11)$ & $87,5(35)$ & Žindymas & $87,1(27)$ & $88,2(15)$ & $72,7(16)$ \\
\hline $28,6(4)$ & $37,5(6)$ & $25,0(10)$ & Supimas & $22,6(6)$ & $29,4(5)$ & $36,4(8)$ \\
\hline $92,9(13)$ & $75,0(12)$ & $70,0(28)$ & Suvystymas, glostymas & $71,0(22)$ & $82,4(14)$ & $77,3(17)$ \\
\hline $92,9(13)^{*}$ & $68,8(11)$ & $60,0(24)$ & Rami aplinka & $51,6(16)^{*}$ & $94,1(16)$ & $72,7(16)$ \\
\hline $14,3(2)$ & $6,3(1)$ & $12,5(5)$ & Grynas oras & $12,9(4)$ & $11,8(2)$ & $9,1(2)$ \\
\hline \multicolumn{4}{|c|}{$* \mathrm{p}<005$, lyginant $\mathrm{su}<5 \mathrm{~m}$. ir 5-10 m. } & \multicolumn{3}{|c|}{$\begin{array}{l}* p<0,05 \text {, lyginant su aukštuoju (neuniversitetiniu ir } \\
\text { universitetiniu) }\end{array}$} \\
\hline
\end{tabular}


tus, nerekomenduojamus naujagimių skausmo malšinimui, atsižvelgiant ị išsimokslinimą, nustatème statistiškai reikšmingus skirtumus tarp grupių. Apie trečdalio (32,3 proc., $\mathrm{n}=10$ ) tyrime dalyvavusių respondentų, turinčių aukštesnijj išsimokslinimą, nuomone, naujagimių skausmo malšinimui nerekomenduojamas naudoti acetaminofenas (paracetamolis). Taip manė reikšmingai mažiau respondentų, turinčių aukštaji neuniversitetini ( 5,9 proc., $n=1)$ ir aukštaji universitetini $(9,1$ proc., $n=2)$ išsimokslinimą $(p=0,031)$.

Didesnè dalis respondentų, atsižvelgiant ị išsimokslinimą, mané, kad naujagimių skausmo malšinimui nerekomenduojama naudoti ibuprofeno (aukštesnysis $-71,0$ proc., $n=22$; aukštasis neuniversitetinis $-76,5$ proc., $n=10$; aukštasis universitetinis $-81,8$ proc., $\mathrm{n}=22$ ); metamizolo natrio druskos (analgino) (aukštesnysis - 80,6 proc. ( $\mathrm{n}=25)$; aukštasis neuniversitetinis. - 82,4 proc. $(\mathrm{n}=14)$; aukštasis universitetinis - 77,3 proc. $(\mathrm{n}=17)$, fentanilio (aukštesnysis - 61,3 proc. $(\mathrm{n}=19)$; aukštasis neuniversitetinis 52,9 proc. $(\mathrm{n}=9)$; aukštasis universitetinis $-50,0$ proc. $(\mathrm{n}=11)$ ), ketamino (aukštesnysis - 61,3 proc. $(n=19)$; aukštasis neuniversitetinis - 64,7 proc. $(n=11)$; aukštasis universitetinis 59,1 proc. $(n=13)(p>0,05)$ (5 lentelè).

Analizuojant tyrimo rezultatus, atsižvelgiant ị slaugytojų darbo patirtį, nustateme statistiškai reikšmingus skirtumus tarp grupių. Apie trečdalio slaugytojų, turinčių didesnę nei 10 m. darbo patirti ( 30,0 proc. $(n=12)$ nuomone, nerekomenduojama naudoti naujagimio skausmo malšinimui acetaminofeno (paracetamolio), tačiau taip manè tik maža dalis slaugytojų,

4 lentelè. Slaugos specialistų taikomi farmakologiniai skausmo malšinimo metodai, atsižvelgiant į darbo patirtị ir išsimokslinimą

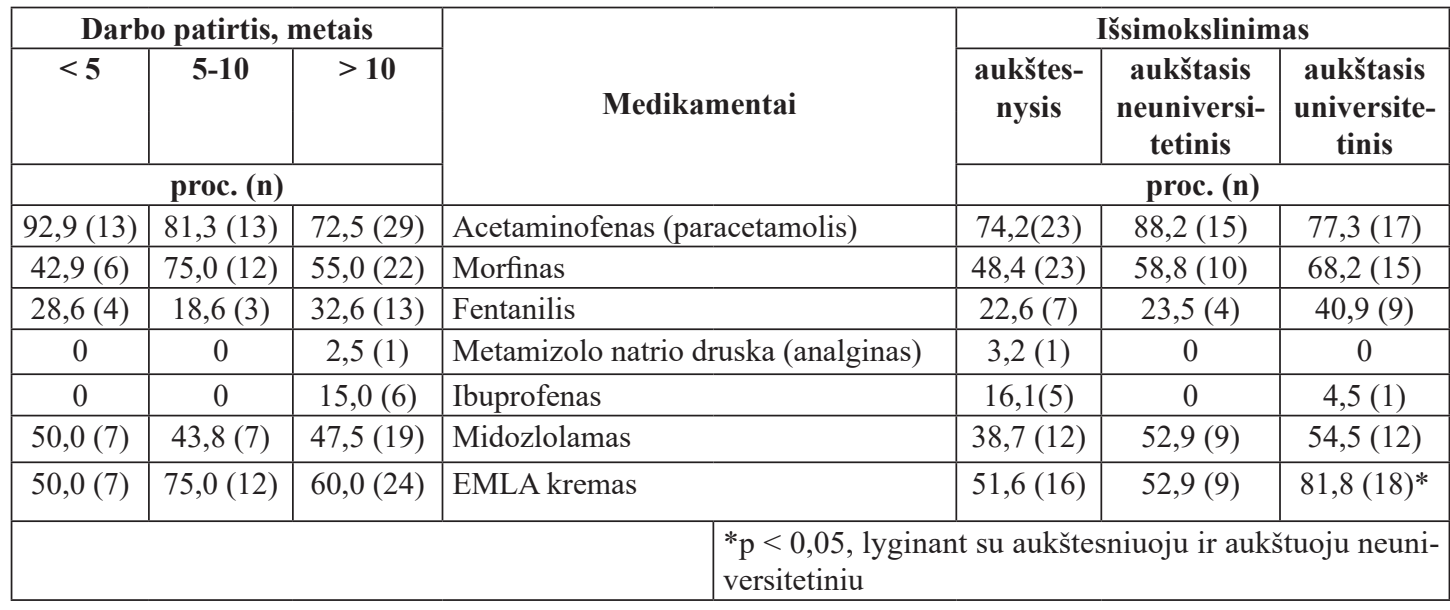

5 lentelè. Slaugos specialistų nuomonė apie naujagimių skausmo malšinimui nerekomenduojamus medikamentus, atsižvelgiant ị darbo patirtị ir išsimokslinimą

\begin{tabular}{|c|c|c|c|c|c|c|}
\hline \multicolumn{3}{|c|}{ Darbo patirtis, metais } & \multirow{4}{*}{ Medikamentai } & \multicolumn{3}{|c|}{ Išsimokslinimas } \\
\hline \multirow[t]{2}{*}{$<5$} & 5-10 & \multirow[t]{3}{*}{$>10$} & & \multirow{2}{*}{$\begin{array}{c}\text { aukštes- } \\
\text { nysis }\end{array}$} & \multirow{2}{*}{$\begin{array}{c}\text { aukštasis } \\
\text { neuniver- } \\
\text { sitetinis }\end{array}$} & \multirow{2}{*}{$\begin{array}{c}\text { aukštasis } \\
\text { universite- } \\
\text { tinis }\end{array}$} \\
\hline & & & & & & \\
\hline \multicolumn{2}{|c|}{ proc. $(n)$} & & & & proc. (n) & \\
\hline 0,0 & $6,3(1)$ & $20(8)$ & EMLA kremas & $22,6(7)$ & $5,9(1)$ & $4,5(1)$ \\
\hline $71,4(10)$ & $87,5(14)$ & $72,5(29)$ & Ibuprofenas & $71,0(22)$ & $76,5(13)$ & $81,8(18)$ \\
\hline $78,6(11)$ & $75,0(12)$ & $82,5(33)$ & Metamizolo natrio druska (analginas) & $80,6(25)$ & $82,4(14)$ & $77,3(17)$ \\
\hline 0,0 & $6,3(1)$ & $30,0(12)^{*}$ & Acetaminofenas (paracetamolis) & $32,3(10)^{*}$ & $5,9(1)$ & $9,1(2)$ \\
\hline $21,4(3)$ & $6,3(1)$ & $50,0(20)^{*}$ & Fentanilis & $61,3(19)$ & $52,9(9)$ & $50,0(11)$ \\
\hline $78,6(11)$ & $56,3(9)$ & $75,0(30)$ & Finlepsinas & $71,0(22)$ & $88,2(15)$ & $59,1(13)$ \\
\hline $71,4(10)$ & $37,5(6)^{*}$ & $67,5(13)$ & Ketaminas & $61,3(19)$ & $64,7(11)$ & $59,1(13)$ \\
\hline $92,6(13)$ & $81,6(13)$ & $85,0(34)$ & Nimesilis & $80,6(25)$ & $94,1(16)$ & $86,6(19)$ \\
\hline \multicolumn{4}{|c|}{$* \mathrm{p}=0,018$, lyginant $\mathrm{su}<5 \mathrm{~m}$. ir 5-10 m. } & int su a & uoju (n & rsitetini \\
\hline
\end{tabular}


turinčiu $5-10 \mathrm{~m}$. darbo patirti ( 6,3 proc. $(\mathrm{n}=1)$ ir nei vienas slaugytojas, turintis mažesnị nei $5 \mathrm{~m}$. $(\mathrm{p}=0,018)$.

Apie pusė slaugytojų, dalyvavusių tyrime ir turinčių didesnę nei $10 \mathrm{~m}$. darbo patirtị (50,0 proc. $(\mathrm{n}=20)$, nurodè, kad fentanilio nerekomenduojama naudoti naujagimio skausmo malšinimui, tačiau taip manè tik apie penktadalis $(21,4$ proc. $(n=3)$ slaugytojų, turinčių mažesnį nei $5 \mathrm{~m}$. ir tik maža dalis slaugytojų, turinčių $5-10 \mathrm{~m}$. darbo patirtį $(6,3$ proc. $(\mathrm{n}=1)$ $(\mathrm{p}=0,004)$.

Statistiškai reikšmingai mažesnė dalis slaugytojų, turinčių 5 - $10 \mathrm{~m}$. darbo patirti $(37,5$ proc. $(\mathrm{n}=6)$, lyginant su slaugytojais, turinčiais mažiau nei $5 \mathrm{~m}$. $(71,4$ proc. $(\mathrm{n}=10)$ ir daugiau nei $10 \mathrm{~m}$. (67,5 proc. $(\mathrm{n}=13)$ darbo patirti, manè, kad ketaminas nerekomenduojamas naudoti naujagimio skausmo malšinimui $(\mathrm{p}=0,047)(5$ lentelè).

\section{Diskusija}

Apie skausmo valdymą kalbama vis dažniau, tačiau ši problema išlieka aktuali. Naujagimysteje ar kūdikystejje pasikartojantys skausmingi dirgikliai sukelia tiek trumpalaiki, tiek ilgalaikị poveikị ir turi ịtakos tolimesnei vaiko raidai [3]. Mūsų atlikto tyrimo rezultatai atskleidè, kad didesnè dalis tyrime dalyvusių slaugos specialistų žinojo apie galimą nenumalšinto skausmo neigiamą poveikị naujagimiams, tačiau penktadalio slaugytojų nuomone, nenumalšintas skausmas jokios žalos nedaro.

Slaugytojams gali būti sunku ịvertinti naujagimio skausmą, todèl skausmo vertinimo skalių naudojimas yra būtina veiksmingo naujagimių skausmo malšinimo sąlyga $[8,9]$. Suomijoje (2018) atlikto tyrimo rezultai atskleidè, kad dauguma tyrime dalyvavusių slaugytojų sutiko, jog naujagimiu skausmo vertinimas turi įtakos skausmo valdymui (95,2 proc.), todèl, slaugant naujagimì būtinas sistemingas skausmo vertinimas (93,2 proc.), naudojant skausmo vertinimo skales (86,4 proc.) [10].

N. Witt ir kt. (2016) naujagimių skausmo vertinimo ir malšinimo rekomendacijose teigiama, kad taikant standartizuotus skausmo vertinimo ir valdymo metodus, geriau malšinamas ūminis naujagimių skausmas, geresni naujagimiu ilgalaikiai neurologiniai ir elgesio rezultatai, didesnis tèvu pasitenkinimas teikiamomis paslaugomis [12].

Kai kurių tyrimų rezultatai rodo, kad klinikinèje praktikoje skausmo vertinimo skalès vis dar nepakankamai naudojamos $[6,10]$. Brazilijoje (2017) vykdyto tyrimo rezultatai atskleidè, jog apie trečdalis (374,7 proc.) slaugytojų, vertindamos naujagimio skausmą, niekada nenaudoja skausmo vertinimo skalių [6]. Mūsų vykdyto tyrimo rezultatai parodè, kad didžiosios dalies tyrime dalyvusių slaugytojų nuomone, gali būti sunku įvertinti naujagimio skausmą dẻl riboto bendravimo, susijusio su amžiumi.
T. Pölkki ir kt. (2018) atlikto tyrimo rezultatai atskleidè, kad labiau patyrę slaugytojai naudojo skausmo vertinimo skales dažniau, nei mažiau patyrusieji [10]. Analizuojant mūsų tyrimo rezultatus, didžioji dalis tyrimo dalyvių teigè, kad vertindami naujagimių skausmą naudoja skales, tačiau reikšmingų skirtumų tarp darbo patirties grupių nenustatyta. Suomijoje (2018) daugiau nei pusè tyrimo dalyvių mané, kad jie gali patikimai ịvertinti naujagimio skausmą, nenaudodami skausmo vertinimo skalių [10]. Švedijoje ir Norvegijoje (2018) atlikto tyrimo metu, kuris vyko NITS ir naujagimiu ligų skyriuose, tyrimo rezultatai buvo skirtingi. Švedijoje slaugytojai vertino ir dokumentavo skausmą bei naudojo skausmo vertinimo skales dažniau, nei Norvegijoje [15].

Analizuojant skausmo valdymo metodus, rekomenduojama atsižvelgti ị skausmo intensyvumą ir naujagimių skausmo malšinimui taikyti nefarmakologinius bei farmakologinius skausmo malšinimo metodus $[7,8,14]$. Nustatyta, kad naujagimiui atliekant tokias procedūras, kaip dūris ị kulną ar venos punkcija, žindymas susijęs su mažesne skausmo reakcija, palyginti su tokiomis priemonemis, kaip supimas ar suvystymas. Motinos pienas, maitinant per čiulptuką ar švirkšto pagalba, yra toks pat efektyvus, kaip gliukozės tirpalo naudojimas [16]. Brazilijoje (2017) atlikto tyrimo metu nustatyta, kad slaugytojai dažniausiai skausmo mažinimui naudojo gliukozès tirpalą ( 68,6 proc.) ir čiulptuką (58,8 proc.) [6]. Suomijoje (2018) atlikto tyrimo metu nustatyta, kad dažniausiai buvo pasirenkamas gliukozès tirpalas per čiulptuką ( 79,8 proc. ), o mamoms buvo patarima tęsti žindymą (74,1 proc.), taikyti oda prie odos kontaktą $(56,0$ proc.). Keli respondentai nurodè, kad naujagimio skausmui malšinti naudojo muzikos ịrašus (2,1 proc.) [10].

Mūsų tyrimo rezultatai šiek tiek skyrèsi. Naujagimių skausmui malšinti didžioji dalis respondentų nurodė taikantys gliukozès tirpalą, žindymą, oda prie odos kontaktą, suvystymą, o muziką, kaip nefarmakologini skausmo malšinimo metodą, taikè apie dešimtadalis slaugytojų. Esant intensyviam naujagimių skausmui, planuojant skausmingas procedūras ar esant neveiksmingiems nefarmakologiniams skausmo malšinimo metodams, rekomenduojama taikyti farmakologinius skausmo malšinimo metodus. Brazilijoje (2017) vykdyto tyrimo rezultatai atskleidè, kad malšindami naujagimio skausmą, slaugytojai dažniausiai naudojo acetaminofeną (paracetamolį) ir fentanili ( 47,1 proc.) bei morfiną (17,6 proc.) [6]. Mūsų atlikto tyrimo rezultatai buvo panašūs. Slaugytojai nurodè, kad dažniausiai naujagimio skausmui malšinti naudoja acetaminofeną (paracetamolị), morfiną, midozolamą, apie puse tiriamujų nurodè naudojantys fentanili.

Galima daryti prielaidą, kad yra atotrūkis tarp rekomenduojamų naujagimių skausmo valdymo gairių ir klinikinès praktikos, nes ne visi slaugytojai gerai išmano apie galimą 
skausmo žalą naujagimiams, ne visada ịvertina naujagimio skausmą, o vertinimui ne visada naudoja skausmo vertinimo skales. Siekiant užtikrinti kokybišką slaugą ir naujagimių skausmo valdymą, svarbu skatinti slaugytojus dalyvauti naujagimių skausmo valdymo mokymuose, kad teorinès žinios būtų plačiau taikomos profesinèje praktikoje.

\section{Išvados}

1. Didžioji dalis slaugos specialistų, turinčių aukštajj universitetinị ir aukštajj neuniversitetinị išsimokslinimą bei mažesnę darbo patirtį, lyginant su turinčiais aukštesnijị išsimokslinimą bei didesnę darbo patirtį, geriau žinojo apie skausmo žalą naujagimiams, skausmo vertinimo ypatumus naudojant PIPP skalę, nerekomenduojamus medikamentus malšinti naujagimių skausmą.

2. Tyrimo dalyviai nurode, kad klinikinejje praktikoje dažniau naujagimių skausmo vertinimui naudojo PIPP skalę, taikè nemedikamentinius skausmo malšinimo metodus, naudojo vietinį nuskausminimą EMLA kremu bei medikamentą acetaminofeną (paracetamolị).

\section{Literatūra}

1. Trachsel LA, Cascella M. Pain theory. StatPearls Publishing 2019.

https://www.ncbi.nlm.nih.gov/books/NBK545194/

2. Raja SN, Carr DB, Cohen M, Finnerup NB, Flor H, Gibson S, et al. The revised International association for the study of pain definition of pain: concepts, challenges, and compromises. Pain 2020;161(9):1976-1982.

https://doi.org/10.1097/j.pain.0000000000001939

3. Doesburg SM, Chau CM, Cheung TP, Moiseev A, Ribary U, Herdman AT, et al. Neonatal pain-related stress, functional cortical activity and visual-perceptual abilities in schoolage children born at extremely low gestational age. Pain 2013;154(10):1946-1952.

https://doi.org/10.1016/j.pain.2013.04.009

4. Cruz MD, Fernandes AM, Oliveira CR. Epidemiology of painful procedures performed in neonates: a systematic review of observational studies. European Journal of Pain 2020;20(4):489-498.

https://doi.org/10.1002/ejp.757

5. Anand KJ, Eriksson M, Boyle EM, Avila-Alvarez A, Anderse RD, Sarafidis K, et al. Assessment of continuous pain in newborns admitted to NICU s in $18 \mathrm{E}$ uropean countries. Acta paediatrica 2017;106(8):1248-1259.

https://doi.org/10.1111/apa.13810

6. Costa T, Rossato LM, Bueno M, Secco IL, Sposito NP, Harrison D, Freitas JS. Nurses' knowledge and practices regarding pain management in newborns. Rev Esc Enferm USP 2017;6(51):e03210.

https://doi.org/10.1590/s1980-220x2016034403210
7. Herr K, Coyne PJ, Ely E, Gélinas C, Manworren, RC. Pain assessment in the patient unable to self-report: Clinical practice recommendations in support of the ASPMN 2019 position statement. Pain Management Nursing 2019;20(5),404-417. https://doi.org/10.1016/j.pmn.2019.07.005

8. AAP committee on fetus and newborn and section on anesthesiology and pain medicine. Prevention and management of procedural pain in the neonate: an update. Pediatrics 2016; 137(2):e2015427. https://doi.org/10.1542/peds.2015-4271

9. Harris J, Ramelet AS, van Dijk M, Pokorna P, Wielenga J, Tume L, Tibboel D, Ista E. Clinical recommendations for pain, sedation, withdrawal and delirium assessment in critically ill infants and children: an ESPNIC position statement for healthcare professionals. Intensive Care Med 2016; 42(6):972-86. https://doi.org/10.1007/s00134-016-4344-1

10. Pölkki T, Korhonen A, Laukkala H. Nurses' perceptions of pain assessment and management practices in neonates: a cross-sectional survey. Scandinavian journal of caring sciences 2018;32(2): 725-733. https://doi.org/10.1111/scs.12503

11. Beltramini A, Milojevic K, Pateron D. Pain assessment in newborns, infants, and children. Pediatric annals 2017;46(10):e387-e395. https://doi.org/10.3928/19382359-20170921-03

12. Witt N, Coynor S, Edwards C, Bradshaw H. A guide to pain assessment and management in the neonate. Current emergency and hospital medicine reports 2016;4(1):1-10. https://doi.org/10.1007/s40138-016-0089-y

13. Lietuvos Respublikos sveikatos apsaugos ministro $2019 \mathrm{~m}$. liepos 12 d. įsakymas Nr.V-828, ,Dèl Lietuvos Respublikos sveikatos apsaugos ministro $2011 \mathrm{~m}$. birželio 8 d. įsakymo Nr. V-591 „Dèl Lietuvos medicinos normos MN 28:2011 „Bendrosios praktikos slaugytojas. Teisès, pareigos, kompetencija ir atsakomybé“ patvirtinimo" pakeitimo". TAR, 2019-07-15, Nr. 11623.

https://e-seimas.lrs.lt/portal/legalAct/lt/TAD/024dd4c1a6d911 e9aab6d8dd69c6da66?jfwid=-wsolgkigh

14. Aldakauskienė I, Brinkis R, Drazdienė N, Drejerienė V, Jasinauskas R, Kregždienè E. Perinatologijos praktikos vadovas. Ketvirtoji knyga: skubioji neonatologinė pagalba. Naujagimių skausmo malšinimas, 2016:35-40. https://sam.lrv.lt/uploads/ sam/documents/files/Veiklos_sritys/Programos_ir_projektai/ Sveicarijos_parama/4\%20knyga_\%20Skubioji\%20neonatologine $\% 20$ pagalba.pdf.

15. Andersen RD, Munsters JM, Vederhus BJ, Gradin M. Pain assessment practices in Swedish and Norwegian neonatal care units. Scandinavian Journal of Caring Sciences 2018;32(3):1074-1082.

https://doi.org/10.1111/scs.12553

16. Shah PS, Aliwalas LI, Shah V. Breastfeeding or breast milk for procedural pain in neonates. Cochrane Database Syst Rev 2012;12:1-96.

https://doi.org/10.1002/14651858.CD004950.pub3 


\section{KNOWLEDGE AND ACTIVITIES OF NURSING PROFESSIONALS IN MANAGING NEONATAL PAIN S. Kostyliovienė, A. Vaškelytė, D. Grinkevičiūtė, G. Seniūnaitė, R. Vainutytè}

Keywords: newborns, pain assessment and relief, knowledge and activities of nursing professionals.

\section{Summary}

Newborns in need of treatment, intensive care and hospital care experience on average 7.5 to 17.3 painful procedures per day. The most common procedures are the stab in the heel for blood sample, secretions suction from the respiratory tract and puncture of the vein. Studies have shown that unmanaged pain affects the further development of the child. Healthcare professionals may find it particularly difficult to assess pain in a premature, severely ill baby or those with neurological problems. Pain scales are recommended for pain assessment. When reducing pain in newborns, stepwise pain relief is recommended using environmental, nonpharmacological and pharmacological methods.

The purpose of this study is to analyse the knowledge and activities of nursing professionals in managing the pain of newborns, taking into account education and work experience.

The study took place from 4.11.2019 to 15.12 .2019 in city hospitals and maternity homes, conducting an anonymous qu- estionnaire survey of nursing professionals. 120 questionnaires were distributed and returned suitable for analysis 70. Response rate: $58.33 \%$.

In the analysis of the study data, the distribution of the attributes concerned in the sample was described as a percentage rate (\%) . The difference in evidence between the groups of subjects was considered statistically significant at the level $\mathrm{p}<0.05$.

The results of the study revealed that the vast majority of nursing professionals with higher university, higher non-university education and lower work experience were aware of the pain harm to newborns, the peculiarities of pain assessment using the PIPP scale, and the unrecommended medications for pain relief in newborns, compared to those with lower education level and longer work experience.

The study participants indicated that in clinical practice, PIPP scale for neonatal pain assessment, non-medial pain relief techniques, and local anaesthesia with EMLA cream and acetaminophen (paracetamol) were used more often.

Correspondence to: silva.kostylioviene@go.kauko.lt

Gauta 2020-10-23 